\title{
Boosting Electrical Performance of CIGS Solar Cells: Buffer Layer Effect
}

\author{
B. Zaidi ${ }^{a, *}$, M. Zouagri ${ }^{a}$, S. Merad ${ }^{a}$, C. Shekhar $^{b}$, B. Hadjoudja ${ }^{c}$ And B. Chouial $^{c}$ \\ ${ }^{a}$ Department of Physics, Faculty of Material Sciences, University of Batna 1, Batna, Algeria \\ ${ }^{b}$ Department of Applied Physics, Amity University Gurgaon, Haryana, 122413, India \\ ${ }^{c}$ Laboratory of Semiconductors, Department of Physics, University of Badji-Mokhtar, Annaba, Algeria
}

(Received April 21, 2019; in final form September 5, 2019)

The effect of the buffer layer in two different solar cell configurations such as $\mathrm{ZnO} / \mathrm{CdS} / \mathrm{CIGS}$ and $\mathrm{ZnO} / \mathrm{SnS} / \mathrm{CIGS}$ on the current density $(J-V)$, generated power $(P-V)$, and efficiency of the solar cells has been studied. Solar cell with $\mathrm{SnS}$ as buffer layer shows better performance and therefore the effect of the ambient temperature on the characteristics of this solar cell has been studied. Additionally, the effect of series and shunt resistance has been studied. The current density, generated power, and the efficiency of the solar cell increase when the buffer layer $\mathrm{SnS}$ is used. The thickness of the absorbent layer is also found to affect the efficiency of the solar cell significantly and optimal thickness is found to be $18 \mu \mathrm{m}$. We found substantial improvement in power conversion efficiency from $12.5 \%$ to $22.5 \%$ due to a decrease in series resistance. The increase in the ambient temperature decreases the current density of the solar cells significantly.

DOI: 10.12693/APhysPolA.136.988

PACS/topics: thin film, solar cells, CdS, SnS, CIGS, SCAPS-1D

\section{Introduction}

With the increased demand for the electric power from solar photovoltaic modules at lower costs, there is a need for novel light absorbing materials that can promise comparable conversion efficiencies at lower manufacturing costs than the incumbent crystalline silicon [1-3] or thin films (CdTe or CIGS) [4-6] based technologies. The CIGS based solar cell technology complies with the best performance of thin-film photovoltaic panel technologies. In recent decades, the performance of these cells has been significantly improved. This research evaluates the effect of tin-suite of absorber materials based on tin monosulfide, SnS and cooper zinc tin sulphide (CZTS) as the next generation of photovoltaic cells that can have the desired performance in the long run. Numerical models have been developed using analysis of microelectronic and photonic structures simulator structures (SCAPS) software program. This study was undertaken by means of solar cell capacitance simulator structures (SCAPS-1D) software [7-9] to analyse the CIGS solar cells. This simulation program was developed by department of electronics and information system (ELIS), at University of Gent, Belgium. It has been extensively tested in solar cells by Burgelman et al. [10, 11].

\section{Material parameters}

Figure 1 shows a schematic representation of CIGS based cell. The illuminated $n$ region (emitter) is on

\footnotetext{
*corresponding author; e-mail: zbeddiaf@gmail.com
}

the left and the $p$ region, thicker (collector) is on the right side in Fig. 1. The solar cell structure consists of three different layers: (1) $\mathrm{ZnO},(2) \mathrm{CdS}$ or SnS, (3) CIGS. The two individual configuration can be represented as (i) $\mathrm{ZnO} / \mathrm{SnS} / \mathrm{CIGS}$, (ii) $\mathrm{ZnO} / \mathrm{CdS} /$ CIGS. The effect of middle layer, also known as the buffer layer, has been presented in this study.

The structure present in Fig. 1 has been studied under the following parameters: solar spectrum AM1.5, $P=100 \mathrm{~mW} / \mathrm{cm}^{2}$, and $T=300 \mathrm{~K}$. The measurements of the photovoltaic parameters were made in the case of a zero series resistance and an infinitely large shunt resistance. The details of parameters used in the simulation is given in Table I.

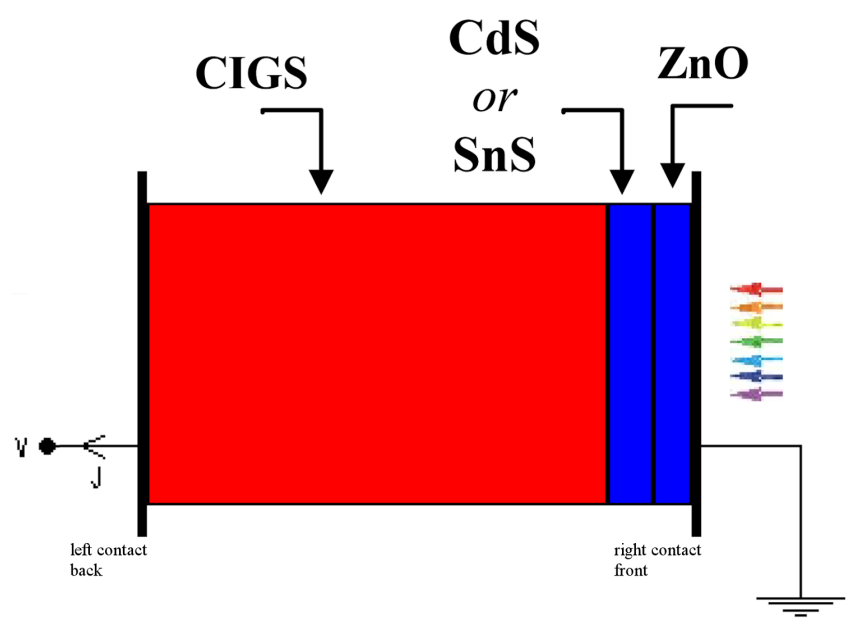

Fig. 1. Schematic diagram of the solar cell studied. 
TABLE I

The parameters of the material used for the simulation of a CIGS based solar cell.

\begin{tabular}{l|c|c|c|c}
\hline \hline \multicolumn{1}{c|}{ Parameters } & $n$-ZnO & $n$-SnS & $n$-CdS & $p$-CIGS \\
\hline thickness $[\mu \mathrm{m}]$ & 0.080 & 0.100 & 0.100 & $0.25-18$ \\
$E_{g}[\mathrm{eV}]$ & 3.4 & 1.25 & 2.45 & 1.2 \\
electron affinity $[\mathrm{eV}]$ & 4.55 & 4.20 & 4.40 & 4.5 \\
$\mu_{n}\left[\mathrm{~cm}^{2} /(\mathrm{V} \mathrm{s})\right]$ & 100 & 100 & 100 & 100 \\
$\mu_{p}\left[\mathrm{~cm}^{2} /(\mathrm{V} \mathrm{s})\right]$ & 25 & 25 & 25 & 25 \\
$N_{a}\left[\mathrm{~cm}^{-3}\right]$ & $10^{14}$ & $10^{14}$ & $10^{14}$ & $10^{14}$ \\
$N_{d}\left[\mathrm{~cm}^{-3}\right]$ & $10^{20}$ & $10^{20}$ & $10^{20}$ & $10^{6}$
\end{tabular}

\section{Result and discussion}

The effect of the thickness of the absorbent layer CIGS on the efficiency is presented in Fig. 2. This figure shows an increase in efficiency with the increase in the thickness of the CIGS layer. A maximum efficiency of $22.49 \%$ is achieved with a thickness of $18 \mu \mathrm{m}$ for $\mathrm{SnS}$ layer. The efficiency decreases significantly when the thickness of the CIGS is reduced below $4 \mu \mathrm{m}$. This shows that the probability of the recombination of the generated conveyors is greater in the vicinity of the rear contact. When the carriers reach the absorber layer CIGS (the junction $p-n)$, they will recombine in the $\mathrm{SnS}$ buffer layer, or they will flow in the absorber layer CIGS, which decreases the density of the photogenerated current which implies the decrease of the conversion efficiency. We conclude that a threshold thickness should be chosen to obtain the optimal electrical efficiency. In present study the optimal thickness was found to be $18 \mu \mathrm{m}$.

This study enables to find the optimum thickness $(18 \mu \mathrm{m})$ of the absorbent layer CIGS which give the best efficiency.

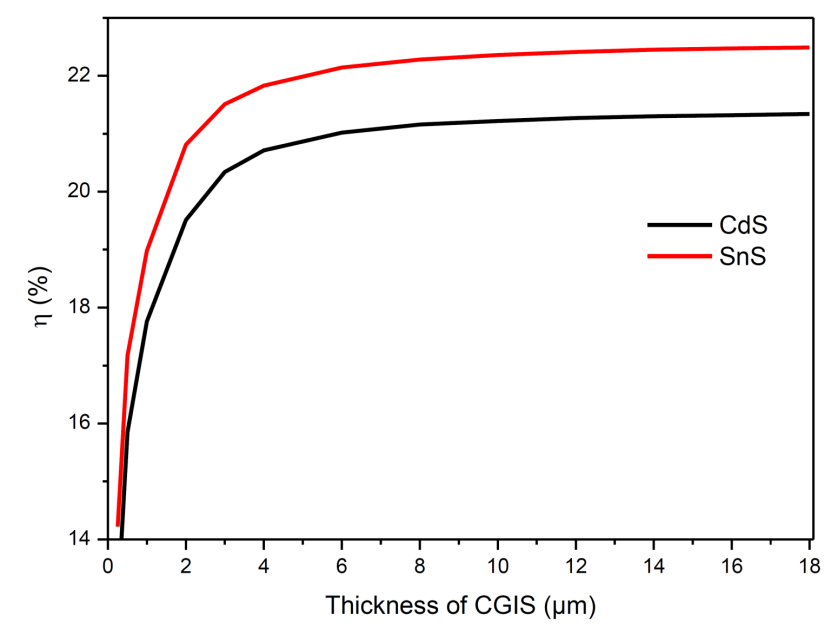

Fig. 2. Influence of the thickness of the absorbent layer CIGS on the efficiency.

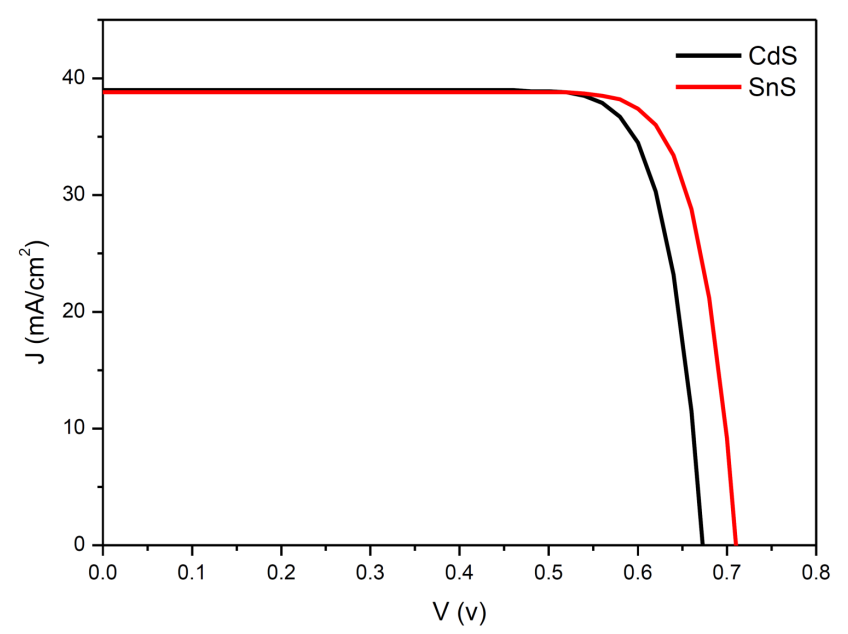

Fig. 3. Influence of the buffer layer on the curve $J-V$.

Photovoltaic quantities of the two cells.

TABLE II

\begin{tabular}{l|c|c}
\hline \hline $\begin{array}{c}\text { Solar cell } \\
\text { configuration }\end{array}$ & $\mathrm{ZnO} / \mathrm{SnS} / \mathrm{CIGS}$ & $\mathrm{ZnO} / \mathrm{CdS} / \mathrm{CIGS}$ \\
\hline$V_{o c}[\mathrm{~V}]$ & 0.71 & 0.67 \\
$J_{s c}\left[\mathrm{~mA} / \mathrm{cm}^{2}\right]$ & 38.82 & 38.99 \\
$\mathrm{FF}[\%]$ & 81.49 & 81.23 \\
$\eta[\%]$ & 22.49 & 21.34 \\
$V_{\mathrm{MPP}}[\mathrm{V}]$ & 0.61 & 0.57 \\
$J_{\mathrm{MPP}}\left[\mathrm{mA} / \mathrm{cm}^{2}\right]$ & 37.1 & 37.19
\end{tabular}

The characteristic variation of current density with voltage $(J-V)$ for these two cells is presented in Fig. 3. From this figure it can be noted that the current density generated by $\mathrm{ZnO} / \mathrm{SnS} / \mathrm{CIGS}$ solar cell is significantly better than those generated by $\mathrm{ZnO} / \mathrm{CdS} / \mathrm{CIGS}$ solar cell. The improvement is recorded mostly in open circuit voltage, form factor, and conversion efficiency.

The output parameters of the solar cells deduced from the characteristic $(J-V)$ plot are summarized in the comparative Table II.

The variation of the power generated as a function of voltage for the two solar cell configurations is shown in Fig. 4. One can see there the effect of the buffer layer on the characteristic $(\mathrm{P}-\mathrm{V})$ of the solar cell based on a CIGS material with $18 \mu \mathrm{m}$ thickness. It can be observed that there is increased efficiency of the solar cell when $\mathrm{SnS}$ is used as the buffer layer, increasing the output power. During the calculation, the same thicknesses of each layer of the cell have been used. This increase can be attributed to the difference between band gap energies of the two semiconductors leading to efficient conversion of solar energy.

Figure 5 shows the variation of the current density with the voltage $(J-V)$ for the solar cell configuration $\mathrm{ZnO} / \mathrm{SnS} / \mathrm{CIGS}$ with the increase in the ambient temperature from 0 to $60^{\circ} \mathrm{C}$. It can be seen that the increase 


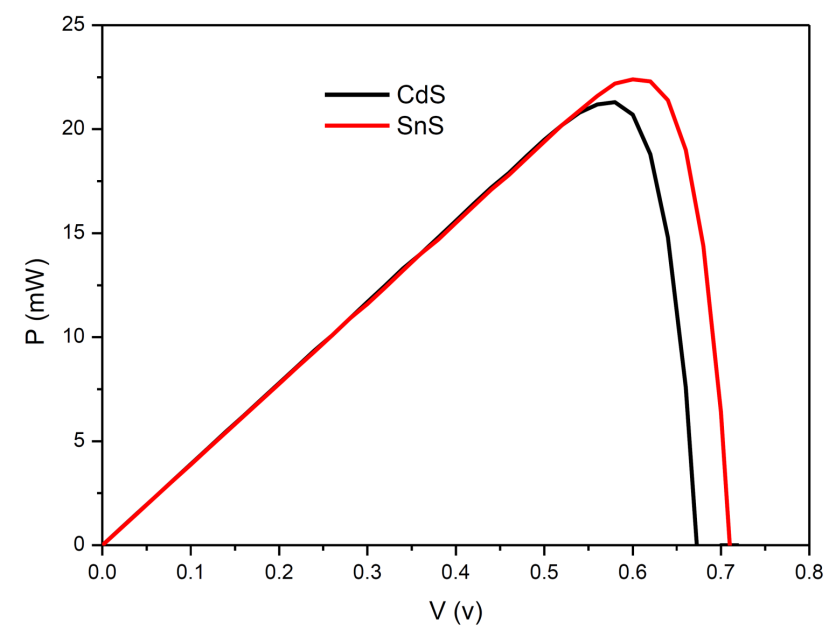

Fig. 4. Influence of the buffer layer on the curve $P-V$.

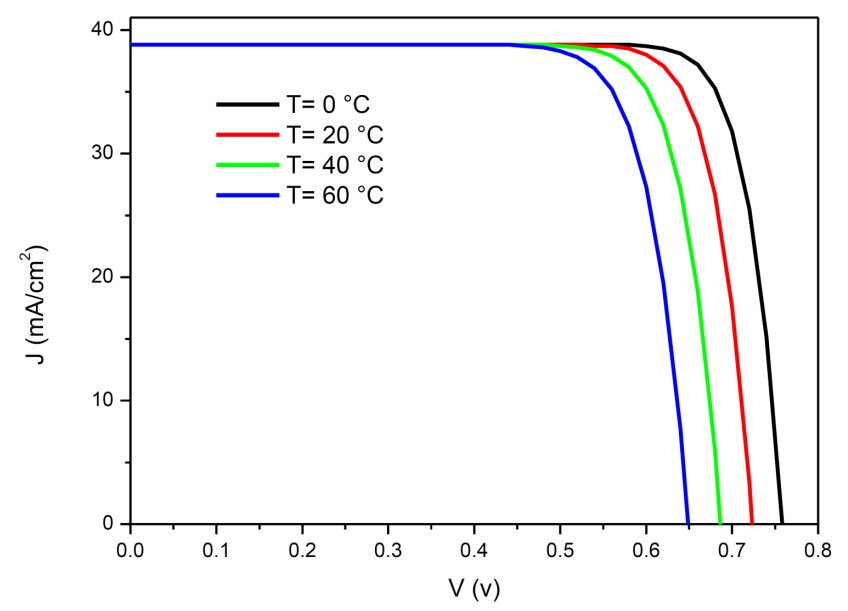

Fig. 5. Influence of the temperature on the curve $J-V$ of $\mathrm{ZnO} / \mathrm{SnS} /$ CIGS.

in temperature leads to a decrease in $V_{c o}$ under constant illumination. Under an irradiance of $1000 \mathrm{~W} / \mathrm{cm}^{2}$ the open circuit voltage, $V_{c o}$, decreases with increasing temperature. There is a decrease in the maximum power output $r$ with increasing temperature.

The effect of shunt resistance variation on efficiency is shown in Fig. 6. It is found that the increase in shunt resistance leads to increase in efficiency. The efficiency undergoes an increase of $15.4 \%$ to $21.27 \%$ as the value of the shunt resistance is increased from 50 to $300 \Omega$. Similar results have been reported in the literature by several authors $[12,13]$.

The effect of the series resistance on the efficiency of the solar cell configuration $\mathrm{ZnO} / \mathrm{SnS} / \mathrm{CIGS}$ is presented in Fig. 7. The increase in the value of the series resistance has been found to cause decrease in the efficiency. Results have been shown in scientific literature [12-14]. The efficiency drops significantly from $22.5 \%$ to $12.5 \%$.

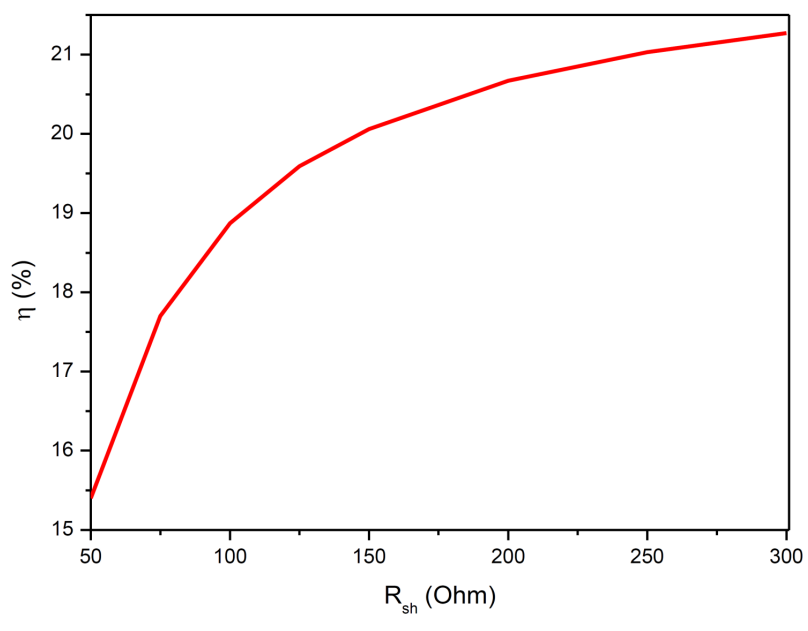

Fig. 6. Influence of shunt resistors on $\mathrm{ZnO} / \mathrm{SnS} / \mathrm{CIGS}$ efficiency.

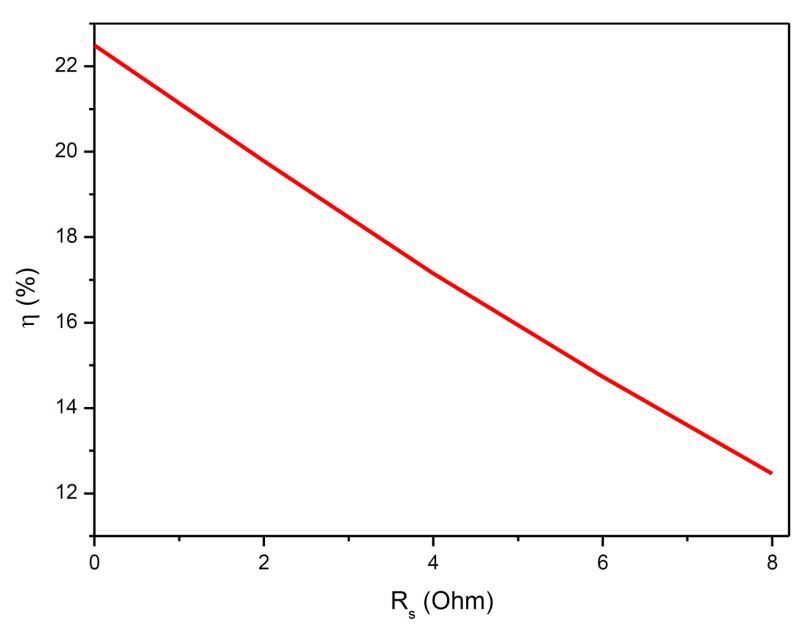

Fig. 7. Influence of series resistances on $\mathrm{ZnO} / \mathrm{SnS} / \mathrm{CIGS}$ solar cell efficiency.

\section{Conclusions}

The effect of the buffer layer, the temperature, and absorbing layer thickness on the $(J-V)$ characteristics has been studied. Additionally, the effect of series and shunt resistance on the efficiency has also been studied. It was observed that the temperature and thickness have a very significant impact on the improvement of the efficiency of the solar cell. Indeed, the variation of absorbing layer thickness can affect the collection of photogenerated charge carriers significantly. Taking into consideration these effects on the efficiency of the solar cells, the thickness of the absorbent layer has been optimized to be $18 \mu \mathrm{m}$. The thickness of the absorbent layer allows the better carrier absorption of short-wavelength photons and a considerable reduction in electrical losses associated with the recombination of the charge carriers at the interface. 


\section{Acknowledgments}

We gratefully acknowledge to Dr. Marc Burgelman, University of Gent, Belgium, for providing the SCAPS-1D simulation software.

\section{References}

[1] O. Martínez, J. Mass, A. Tejero, B. Moralejo, V. Hortelano, M.A. González, J. Jiménez, V. Parra, Acta Phys. Pol. A 125, 1013 (2014).

[2] B. Zaidi, B. Hadjoudja, H. Felfli, B. Chouial, A. Chibani, Rev. Métallurg. 108, 443 (2011).

[3] B. Zaidi, B. Hadjoudja, B. Chouial, K. Kamli, A. Chibani, C. Shekhar, Silicon 10, 2161 (2018).

[4] S. Zaynabidinov, R. Aliev, M. Muydinova, B. Urmanov, Appl. Sol. Energy 54, 395 (2018).

[5] B. Zaidi, C. Shekhar, B. Hadjoudja, S. Gagui, B. Chouial, Acta Phys. Pol. A 136, 495 (2019).
[6] A.O. Pudov, A. Kanevce, H. Al-Thani, J.R. Sites, F.S. Hasoon, J. Appl. Phys. 97, 064901 (2005).

[7] A. Niemegeers, M. Burgelman, J. Appl. Phys. 81, 2881 (1997).

[8] J. Verschraegen, M. Burgelman, Thin Solid Films 515, 6276 (2007).

[9] K. Decock, S. Khelifi, M. Burgelman, Thin Solid Films 519, 7481 (2011).

[10] M. Burgelman, P. Nollet, S. Degrave, Thin Solid Films 361, 527 (2000).

[11] M. Burgelman, J. Verschraegen, S. Degrave, P. Nollet, Prog. Photovolt. Res. Appl. 12, 143 (2004).

[12] J. Ding, X. Cheng, T. Fu, Vacuum 77, 163 (2005).

[13] P. Singh, S.N. Singh, M. Lal, M. Husain, Sol. Energy Mater. Sol. Cells 92, 1611 (2008).

[14] E. Radziemska, Energy Convers. Manage. 46, 1485 (2005). 